\title{
Estimation of the Basic Wood Density of Native Species Using Mixed Linear Models
}

\author{
Jeferson Pereira Martins Silva ${ }^{1}$ (D), Márcia Rodrigues de Moura Fernandes ${ }^{1}$ (D), \\ Anny Francielly Ataide Gonçalves ${ }^{2}$ (D), Isáira Leite e Lopes² (D), \\ Gilson Fernandes da Silva ${ }^{1}$ (D), Christian Dias Cabacinha ${ }^{3}$ (D) \\ ${ }^{1}$ Universidade Federal do Espírito Santo - UFES, Jerônimo Monteiro/ES, Brasil \\ ${ }^{2}$ Universidade Federal de Lavras - UFLA, Lavras/MG, Brasil \\ ${ }^{3}$ Universidade Federal de Minas Gerais - UFMG, Montes Claros/MG, Brasil
}

\begin{abstract}
This paper aimed to estimate the basic density (DB) of the wood of Cerrado species using mixed linear models. For performing the DBH measurement, the sampling of 334 individuals was carried out. By keeping the Pilodyn apparatus in the DBH position, two measurements were made on opposite sides. Further, for determining DB, the trees were knocked down, followed by removal of five wood discs at different height of stem positions. For this purpose, two sets of modeling alternatives were proposed, which take into account with and without random effects, employing species as a random effect grouping variable. Thus, it was elucidated that, for the estimation of DB, the mixed model that considered the random effects performed better as compared to the alternative model without random effects. The inclusion of random effects leads to the estimation of DB with high accuracy.
\end{abstract}

Keywords: Cerrado stricto sensu, wood quality, regression. 


\section{INTRODUCTION}

Basic density (DB) is one of the most important parameters in the evaluation of the wood quality and its utility in wood industry (Rodriguez et al., 2016). However, it constitutes a complex variable as it results from the combination of several factors such as cell wall thickness, vessel volume, parenchyma, fiber size, wood heartwood, sapwood and arrangement of anatomical elements (Foelkel et al., 1971).

Further, depending on the utilization of this factor, one can estimate the forest biomass and carbon stock (Baccini et al., 2012; Saatchi et al., 2011). Thus, knowledge about this basic wood density (DB) of native species aids in the conservation and sustainable exploitation of forests (Chave et al., 2005, 2014; Jati et al., 2014; Djomo et al., 2016).

However, DB estimation is a challenge due to its variability (Leite et al., 2016) with several factors such as genetics (Kimberley et al., 2015), age (Githiomi \& Kariuki, 2010; Sette et al., 2012), site (Meneses et al., 2015), environmental conditions, tree thinning (Latorraca \& Albuquerque, 2000; Oliveira et al., 2012), among species (Vale et al., 2010) and inside the same tree (Henry et al., 2010; Wassenberg et al., 2015).

Generally, traditional regression models are involved in the DB modeling studies (Couto et al., 2013). It takes into consideration several assumptions, such as the independence between observations and homogeneity of variance. But these assumptions are not always fulfilled (Gouveia et al., 2015).

Thus, as an alternative, more accurate statistical techniques such as mixed models are used, which allows generalization of spatiotemporal correlations structures and non-constant variance. Moreover, in comparison to traditional regression models, the mixed models are capable of extracting the relationships of independent variables with clustered data (Calegario et al., 2005; Fausto et al., 2008; Gouveia et al., 2015).

The growing application of mixed models to solve regression problems has been successful in modeling the hypsometric relationship of (Gómez-García et al., 2016; Mendonça et al., 2015; Özçelik et al., 2018) growth in diameter (Bohora \& Cao, 2014; Xu et al., 2014; Ruslandi et al., 2017), mortality (Groom et al., 2012; Zhang et al., 2015) biomass and volume (Meng et al., 2007; Bueno-López \& Bevilacqua, 2012; Guangyi et al.,
2015), and tree taper (Cao \& Wang, 2011). Hence mixed models, which enhances the accuracy of the produced estimates, proves to be a potential technique for modeling the basic density of wood.

Thus, keeping in view the above points, the current investigation focusses on the exploitation of mixed linear models, in place of traditional regression models, for the evaluation of possible gains in accuracy of $\mathrm{DB}$ estimation.

\section{MATERIAL AND METHODS}

\subsection{Location and characterization of area under examination}

The study was carried out in a legal reserve area of 29.6 hectares, located at $16^{\circ} 41^{\prime} \mathrm{S}$ and $43^{\circ} 50^{\prime} \mathrm{W}$ coordinates in the municipality of Montes Claros (Figure 1). According to Köppen (Köppen \& Geiger, 1928), the climate of the region is tropical wet-dry, also termed as Aw, with rainfall being mainly concentrated between October and March months. Further, the average annual precipitation and temperature were found to be $1,060 \mathrm{~mm}$ and $24.2{ }^{\circ} \mathrm{C}$, respectively (INMET, 2013).

Out of 29.6 ha area under examination, just onehectare area $(100 \mathrm{~m} \times 100 \mathrm{~m})$ was chosen for the collection of the database (Figure 1), as it displays a continuous area with the maximum variability of the Cerrado phyto-physiognomy. In this selected area, all the woody trees having life, and diameter at breast height $(\mathrm{DBH})$ equal to or greater than $3.0 \mathrm{~cm}$, were further collected and identified with their respective botanical names. Additionally, the classification used in the present study, adopted at the family level, was according to APG III (2009).

In total, the evaluation of 334 living individuals (distributed in 13 species), not protected by the current legislation, with bark diameter at $1.30 \mathrm{~m}$ of soil height (DBH) equal to or greater than $3 \mathrm{~cm}$. Further, in every individual were measured the $\mathrm{DBH}$, total height $(\mathrm{H})$, and resistance to penetration the Pilodyn apparatus[(PIL)] (Table 1).

Using the Pilodyn apparatus, the penetration resistance was evaluated in all selected individuals by carrying out two measurements on opposite sides of the $\mathrm{DBH}$ position under bark, which in turn assists in calculating the arithmetic mean of the penetration 
depth of the needle in every single individual under examination.

The basic density (DB) of the wood was procured by knocking down the selected trees, followed by removal of five wood discs of approximately $3.0 \mathrm{~cm}$ in thickness at $0 \%, 25 \%, 50 \%, 75 \%$ and $100 \%$ height positions of the tree stem. It was further defined, in the present work, as the height of the commercial stem growing from the ground level to a minimum diameter of $3 \mathrm{~cm}$ with the bark of the main stem of the tree being intact. Furthermore, the estimation of sample volume and dry weight was carried out in the laboratory, where the volume of the sample was calculated using the water displacement method, also
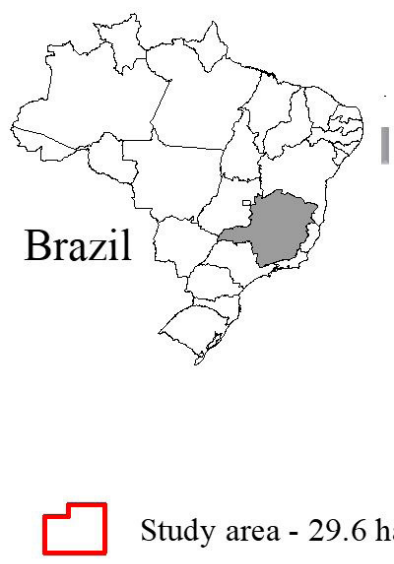

Study area - 29.6 ha

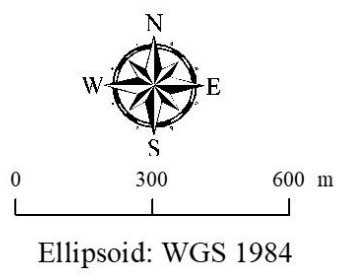

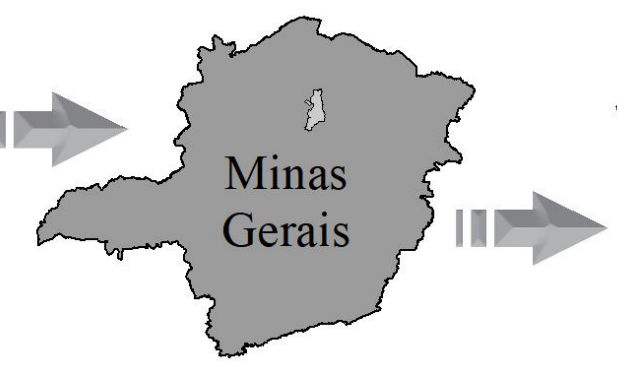

$43^{\circ} 51^{\prime} 0 " \mathrm{~W}$

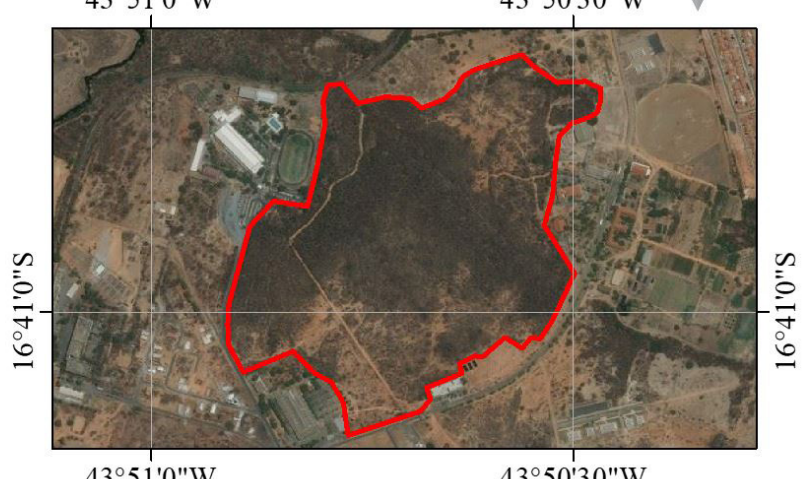

$43^{\circ} 51^{\prime} 0 " \mathrm{~W}$

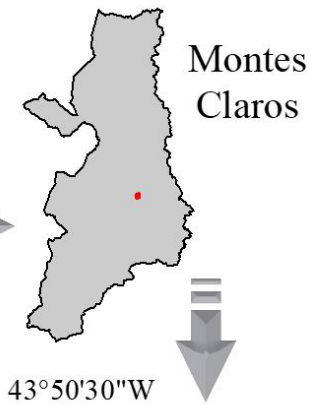

$43^{\circ} 50^{\prime} 30^{\prime \prime} \mathrm{W}$

Figure 1. Location of the study area.

Table 1. Scientific name of the studied species, number of individuals sampled per species with minimum, medium, and maximum values of the diameter at breast height $(\mathrm{DBH})$, total height $(\mathrm{H})$, and resistance to penetration measured using the Pilodyn apparatus (PIL).

\begin{tabular}{|c|c|c|c|c|c|c|c|c|c|c|}
\hline \multirow{2}{*}{ Species } & \multirow{2}{*}{ Amount } & \multicolumn{3}{|c|}{ DBH $(\mathrm{cm})$} & \multicolumn{3}{|c|}{$\mathrm{H}(\mathrm{m})$} & \multicolumn{3}{|c|}{ PIL (mm) } \\
\hline & & $\min$ & average & $\max$ & $\min$ & average & $\max$ & $\min$ & average & $\max$ \\
\hline Luehea paniculata Mart. \& Zucc & 7 & 3.50 & 5.21 & 10.12 & 3.4 & 5.4 & 8.6 & 8.0 & 9.4 & 11.0 \\
\hline Terminalia fagifolia Mart. \& Zucc & 29 & 3.34 & 5.21 & 9.33 & 3.3 & 4.7 & 6.7 & 5.6 & 9.3 & 11.5 \\
\hline Copaifera langsdorffii Desf & 20 & 3.02 & 6.56 & 13.96 & 3.2 & 5.6 & 8.9 & 7.5 & 9.9 & 15.0 \\
\hline Maytenus sp. & 7 & 3.18 & 5.79 & 8.21 & 3.8 & 4.9 & 5.9 & 6.0 & 9.1 & 12.5 \\
\hline Heteropterys byrsonimifolia A. Juss & 120 & 2.93 & 4.80 & 14.45 & 2.7 & 4.3 & 6.8 & 4.8 & 8.5 & 12.0 \\
\hline Tocoyena formosa Cham. \& Schltdl & 19 & 3.34 & 4.56 & 6.94 & 2.7 & 4.2 & 6.5 & 6.5 & 8.5 & 14.0 \\
\hline Machaerium opacum Vog. & 55 & 3.50 & 6.19 & 16.39 & 1.9 & 4.0 & 6.3 & 4.2 & 7.0 & 10.5 \\
\hline Machaerium sp & 7 & 3.92 & 5.45 & 7.32 & 3.9 & 6.8 & 8.8 & 6.5 & 8.0 & 9.0 \\
\hline Curatela americana $\mathrm{L}$ & 22 & 3.72 & 6.39 & 13.81 & 2.0 & 3.5 & 5.8 & 8.5 & 13.4 & 18.0 \\
\hline Byrsonima heterophyla & 13 & 3.25 & 6.43 & 12.11 & 3.2 & 4.7 & 6.2 & 5.5 & 10.3 & 14.5 \\
\hline Combretum leprosum Mart & 12 & 3.63 & 5.37 & 10.82 & 3.0 & 4.1 & 5.5 & 7.8 & 11.2 & 13.5 \\
\hline Dalbergia brasiliensis Vog & 20 & 3.02 & 5.69 & 10.89 & 3.1 & 5.0 & 7.3 & 7.0 & 10.1 & 12.5 \\
\hline Magonia pubescens A.St \& Hil & 7 & 3.02 & 4.52 & 7.00 & 3.3 & 4.3 & 5.9 & 6.5 & 7.5 & 9.0 \\
\hline
\end{tabular}


known as the Archimedes principle. Subsequently, after drying all samples in a greenhouse at $103^{\circ} \mathrm{C}$, the dry weight of each sample was evaluated (ASTM, 2002). Thus, the ratio of the dry weight to the volume of the sample obtained illustrates the DB of the wood at each sampled position. By further calculating the arithmetic mean of the densities in each longitudinal position, the DB of the wood of each tree was estimated.

\subsection{Rated models}

To further validate whether the accuracy of the wood DB estimation of Cerrado native species will improve by the inclusion of the random effect (species), the regression models were adjusted with fixed effect (Equations 1, 2, 3, 4, 5, and 6) and also in the mixed form (Equations 7, 8, 9, 10, 11 and 12).

$$
\begin{aligned}
& \mathrm{DB}_{\mathrm{ij}}=\alpha_{0}+\alpha_{1} \mathrm{PIL}+\varepsilon_{\mathrm{i}} \\
& \mathrm{DB}_{\mathrm{ij}}=\alpha_{0}+\alpha_{2} \mathrm{DBH}+\varepsilon_{\mathrm{i}} \\
& \mathrm{DB}_{\mathrm{ij}}=\alpha_{0}+\alpha_{3} \mathrm{H}+\varepsilon_{\mathrm{i}} \\
& \mathrm{DB}_{\mathrm{ij}}=\alpha_{0}+\alpha_{1} \mathrm{PIL}+\alpha_{2} \mathrm{DBH}+\varepsilon_{\mathrm{i}} \\
& \mathrm{DB}_{\mathrm{ij}}=\alpha_{0}+\alpha_{1} \mathrm{PIL}+\alpha_{3} \mathrm{H}+\varepsilon_{\mathrm{i}} \\
& \mathrm{DB}_{\mathrm{ij}}=\alpha_{0}+\alpha_{1} \mathrm{PIL}+\alpha_{2} \mathrm{DBH}+\alpha_{3} \mathrm{H}+\varepsilon_{\mathrm{i}} \\
& \mathrm{DB}_{\mathrm{ij}}=\left(\beta_{00}+\gamma_{0 \mathrm{j}}\right)+\left(\beta_{01}+\gamma_{1 \mathrm{j}}\right) \mathrm{PIL} \varepsilon_{\mathrm{ij}} \\
& \mathrm{DB}_{\mathrm{ij}}=\left(\beta_{00}+\gamma_{0 \mathrm{j}}\right)+\left(\beta_{02}+\gamma_{2 \mathrm{j}}\right) \mathrm{DBH}+\varepsilon_{\mathrm{ij}} \\
& \mathrm{DB}_{\mathrm{ij}}=\left(\beta_{00}+\gamma_{0 \mathrm{j}}\right)+\left(\beta_{03}+\gamma_{3 \mathrm{j}}\right) \mathrm{H}+\varepsilon_{\mathrm{ij}}
\end{aligned}
$$

$$
\begin{aligned}
& \mathrm{DB}_{\mathrm{ij}}=\left(\beta_{00}+\gamma_{0 \mathrm{j}}\right)+\left(\beta_{01}+\gamma_{1 \mathrm{j}}\right) \mathrm{PIL}+\left(\beta_{02}+\gamma_{2 \mathrm{j}}\right) \mathrm{DBH}+\varepsilon_{\mathrm{ij}}(10) \\
& \mathrm{DB}_{\mathrm{ij}}=\left(\beta_{00}+\gamma_{0 \mathrm{j}}\right)+\left(\beta_{01}+\gamma_{1 \mathrm{j}}\right) \mathrm{PIL}+\left(\beta_{03}+\mathrm{H} \gamma_{3 \mathrm{j}}\right)+\varepsilon_{\mathrm{ij}} \\
& \mathrm{DB}_{\mathrm{ij}}=\left(\beta_{00}+\gamma_{0 \mathrm{j}}\right)+\left(\beta_{01}+\gamma_{1 \mathrm{j}}\right) \mathrm{PIL}+\left(\beta_{02}+\gamma_{2 \mathrm{j}}\right) \mathrm{DBH}+\left(\beta_{03}+\gamma_{3 \mathrm{j}}\right) \mathrm{H}+\varepsilon_{\mathrm{ij}}
\end{aligned}
$$

where: $\alpha_{0}, \alpha_{1}, \alpha_{2}$ and $\alpha_{3}=$ parameters of the fixed-effect model; $\beta_{00}, \beta_{01}, \beta_{02}, \beta_{03}=$ fixed parameters of the mixed model; $\gamma_{0 j}, \gamma_{1 j}, \gamma_{2 j}$ and $\gamma_{3 j}=$ random parameters of the mixed model; $\mathrm{DB}_{\mathrm{ij}}=$ random parameters of the mixed model; PIL = Pylodin; $D B H=$ diameter at breast height; $H=$ total height; $\varepsilon_{\mathrm{ij}}=$ random error.

The models 1 to 6 were adjusted by the ordinary least squares method in R software with the function $\mathrm{lm}$. For the adjustment of the mixed linear models (Models 7 to 12), the maximum likelihood algorithm was used. The type of variance and covariance structure chosen was the diagonal, available in the software package nlme R (R Development Core Team, 2018).

\subsection{Methods for evaluation of estimates accuracy}

Based on the species, data were separated randomly at $70 \%$ for fit and $30 \%$ for validation. Further, depending on the following statistics: adjusted coefficient of determination $\left(\overline{\mathrm{R}}^{2}\right)$, relative bias $[\mathrm{B}(\%)]$, and relative root mean square error [RMSE (\%)] (Equations 13, 14 and 15; Table 2), the estimates generated by the mixed models and the model with only fixed effects were evaluated for both the adjustment and the validation (Table 2).

Table 2. Statistics to evaluate the performance of mixed models and multiple linear regression in the estimation of the $\mathrm{DB}$ of the Cerrado wood species.

\section{Statistics}

Adjusted coefficient of determination $\quad \overline{\mathrm{R}}^{2}=1-\left(\frac{\mathrm{n}-1}{\mathrm{n}-\mathrm{p}}\right)\left[1-\left(1-\frac{\sum_{\mathrm{i}=1}^{\mathrm{n}}\left(\mathrm{Y}_{\mathrm{i}}-\hat{\mathrm{Y}}_{\mathrm{i}}\right)^{2}}{\sum_{\mathrm{i}=1}^{\mathrm{n}}\left(\mathrm{Y}_{\mathrm{i}}-\overline{\mathrm{Y}}_{\mathrm{i}}\right)^{2}}\right]^{2}\right]$

$$
B(\%)=\frac{100}{\bar{Y}} \frac{\sum_{i=1}^{n} Y_{i}-\sum_{i=1}^{n} \hat{Y}_{i}}{n}
$$

$$
\operatorname{RMSE}(\%)=\frac{100}{\bar{Y}} \sqrt{\frac{\sum_{i=1}^{n}\left(Y_{i}-\hat{Y}_{i}\right)^{2}}{n}}
$$

$\mathrm{Y}_{\mathrm{i}}=$ dependent variable observed; $\hat{\mathrm{Y}}_{\mathrm{i}}=$ estimated dependent variable; $\overline{\mathrm{Y}}_{\mathrm{i}}=$ mean of the observed dependent variable; $\mathrm{n}=$ number of observations. 
With the aim of further complementing the statistics, a graph was drawn using the values obtained and estimated by the techniques and graphs of percent residuals. Also, the error percentage of each observation was calculated using Equation 16, shown below:

$\mathrm{E}(\%)=\frac{\mathrm{Y}_{\mathrm{i}}-\hat{\mathrm{Y}}_{\mathrm{i}}}{\mathrm{Y}_{\mathrm{i}}} 100$

where: $\mathrm{E}(\%)=$ percentage error of each observation.

\section{RESULTS}

Upon evaluation of the parameters significance for the multiple linear regression model with all fixed effects using the student $\mathrm{t}$-test, exceptions regarding the parameters associated with $\mathrm{DBH}$ of model 2 , and height $(\mathrm{H})$ of models 3 and 6 , were perceived. Whereas the significance level of all remaining parameters was found to be $5 \%$, indicating their probability of occurring is $5 \%$.

The coefficient associated with non-significant height was demonstrated for model 6 (Table 3). Thus, the most appropriate model for estimation of the basic wood density in the study region was model 4 . Further, the prediction of regression statistics for models 4 and 6, using models with the fixed effects, was more accurate (Table 4 ).

The analysis of the statistics, employed for the corroboration of the mixed models performance regarding adjustment and validation of data (Table 5),

Table 3. Values of the coefficients of various models with fixed effects estimating the basic density of Cerrado wood species.

\begin{tabular}{|c|c|c|c|c|}
\hline Model & Intercept & PIL & $D B H$ & $H$ \\
\hline 1 & $0.763422^{*}$ & $-0.017727^{\star}$ & & \\
\hline 2 & $0.589491^{*}$ & & $0.003167^{\mathrm{ns}}$ & \\
\hline 3 & $0.590297^{*}$ & & & $0.003671^{\mathrm{ns}}$ \\
\hline 4 & $0.736935^{\star}$ & $-0.019765^{*}$ & $0.008264^{*}$ & \\
\hline 5 & $0.734533^{*}$ & $-0.018225^{\star}$ & & $0.007518^{*}$ \\
\hline 6 & $0.730152^{*}$ & $-0.019782^{*}$ & $0.007742^{*}$ & $0.002201^{\mathrm{ns}}$ \\
\hline
\end{tabular}

${ }_{\text {ns }}=$ not significant; PIL = Pylodin; DBH = diameter at breast height; $\mathrm{H}=$ total height; ${ }^{*}$ significance level at $5 \%$ probability by the student $\mathrm{t}$ test.

Table 4. Statistics employed in adjustment and validation for evaluation of the models with fixed effects exploited for the estimation of the DB of Cerrado wood species.

\begin{tabular}{ccccccc}
\multirow{2}{*}{ Model } & \multicolumn{2}{c}{ Fitting } & & \multicolumn{3}{c}{ Validation } \\
\cline { 2 - 3 } \cline { 5 - 7 } & RMSE\% & $\overline{\mathrm{R}}^{2}$ & & RMSE\% & BIAS & $\overline{\mathrm{R}}^{2}$ \\
\hline 1 & 8.35 & 0.37 & & 7.35 & -0.14 & 0.47 \\
2 & 10.40 & 0.01 & & 10.43 & 0.93 & 0.00 \\
\hline 3 & 10.48 & 0.00 & & 10.34 & 0.85 & 0.00 \\
4 & 7.86 & 0.44 & & 7.64 & -0.12 & 0.44 \\
5 & 8.21 & 0.38 & & 7.49 & -0.22 & 0.45 \\
\hline 6 & 7.85 & 0.43 & 7.67 & -0.15 & 0.43 \\
\hline
\end{tabular}

RMSE $(\%)=$ root mean square error; $\overline{\mathrm{R}}^{2}=$ adjusted coefficient of determination; BIAS = relative bias.

Table 5. Statistics used in the adjustment and validation of data for evaluating the application of mixed linear models in the estimation of the DB of Cerrado wood species.

\begin{tabular}{|c|c|c|c|c|c|c|}
\hline \multirow{2}{*}{ Model } & \multicolumn{3}{|c|}{ Fitting } & \multicolumn{3}{|c|}{ Validation } \\
\hline & RMSE\% & BIAS & $\overline{\mathrm{R}}^{2}$ & RMSE\% & BIAS & $\overline{\mathrm{R}}^{2}$ \\
\hline 7 & 5.81 & 0.04 & 0.69 & 5.60 & 0.75 & 0.70 \\
\hline 8 & 5.96 & 0.04 & 0.67 & 5.90 & 1.07 & 0.67 \\
\hline 9 & 5.88 & 0.03 & 0.68 & 5.79 & 1.04 & 0.69 \\
\hline 10 & 5.56 & 0.02 & 0.72 & 5.86 & 0.77 & 0.68 \\
\hline 11 & 5.48 & 0.01 & 0.73 & 5.66 & 0.73 & 0.70 \\
\hline 12 & 5.40 & 0.02 & 0.73 & 5.74 & 0.72 & 0.68 \\
\hline
\end{tabular}

RMSE $(\%)=$ root mean square error; $\overline{\mathrm{R}}^{2}=$ adjusted coefficient of determination; BIAS = relative bias. 
revealed that all models impart low RMSE (\%) and high B (\%) values, thereby indicating that results obtained from all models are of good quality. Therefore, the estimation of the DB with good results can be carried out using any of the above models. However, in the present study preference was given to the Model 11 over the Model 4 (regression model with fixed effects only) for the estimation of the wood DB.

The values of fixed and random effects of Model 11 are presented in Table 6 and 7, respectively.

In the adjustment and validation, most of the data of Model 11 (Figure 2) are in close approximation to the $45^{\circ}$ line (red line) as well as to the zero error line in the residual scatter plot in comparison to Model 4 , with all fixed effects.

Figure 2 further reveals that in both adjustment and validation, histograms of model 11 demonstrated errors in more than $95 \%$ of the cases grouped in the class amplitude of $\pm 10 \%$, whereas histograms of the multiple linear regression model (Model 4) presented errors in $85 \%$ of the cases grouped in the same interval.

\section{DISCUSSION}

The attainment of higher results, in terms of accuracy, in all models with random effects, in comparison to the regression model with only fixed effects, was validated from the analysis of statistical indicators $\left[\overline{\mathrm{R}}^{2}\right.$, RMSE (\%) and B (\%)]. The above observation can be attributed to the ability of mixed linear models to extract the relationships of independent variables with clustered data in a better way (species) as compared to traditional regression models (Calegario et al., 2005; Gouveia et al., 2015).

Thus, one of the primary advantages of the models including the random effects in their structure, compared to the fixed effect models, is the reduction of the residual standard error. This reduction was further reported by Gouveia et al. (2015), who studied the volume of wood in Eucalyptus clones. However, the reduction noted was only 26 times. On the other hand, in the current study, the RMSE reduced from $7.86 \%$ (Table 4 ) to $5.48 \%$ (Table 5), which elucidates a gain in accuracy of approximately $31.21 \%$.

Table 6. Values of the fixed effects coefficients of Model 4 used for the estimation of the DB of Cerrado wood species.

\begin{tabular}{ccccc} 
& Value & Std.Error & t-value & \multicolumn{1}{c}{ p-value } \\
\hline (Intercept) & 0.6309446 & 0.026086759 & 24.186392 & 0 \\
\hline$P I L$ & -0.0068727 & 0.002453106 & -2.801615 & 0.0055 \\
\hline$H$ & 0.0080633 & 0.003663857 & 2.200755 & 0.0288 \\
\hline
\end{tabular}

Table 7. Values of the random effects coefficients of Model 11 employed for the estimation the basic density of Cerrado wood species.

\begin{tabular}{lccc}
\multicolumn{1}{c}{ Group } & $\gamma_{0 \mathrm{j}}$ & $\gamma_{1 \mathrm{j}}$ & $\gamma_{2 \mathrm{j}}$ \\
\hline Luehea paniculata Mart. \& Zucc & -0.00671568 & -0.005109 & -0.00024296 \\
Terminalia fagifolia Mart. \& Zucc & -0.04778732 & 0.0054803 & 0.00088041 \\
Copaifera langsdorffi Desf & 0.05640130 & -0.006009 & -0.00249756 \\
Maytenus sp. & 0.01573392 & 0.0022004 & -0.00108434 \\
\hline Heteropterys byrsonimifolia A. Juss & -0.02077278 & 0.0024771 & -0.00100297 \\
Tocoyena formosa Cham. \& Schltdl & 0.00041378 & 0.0041583 & -0.00088258 \\
Machaerium opacum Vog. & 0.04630224 & 0.0041536 & -0.00154117 \\
Machaerium sp & 0.04079368 & 0.0031197 & -0.01204169 \\
Curatela americana L & -0.07278023 & -0.004694 & 0.01215873 \\
Byrsonima heterophyla & -0.00077800 & -0.006311 & 0.00960528 \\
Combretum leprosum Mart & -0.02528282 & -0.002264 & 0.00252822 \\
Dalbergia brasiliensis Vog & -0.06963246 & 0.0018974 & 0.00301561 \\
\hline Magonia pubescens A.St \& Hil & 0.084104259 & 0.0009007 & -0.00889499 \\
\hline
\end{tabular}

Where: $\gamma_{0 \mathrm{j}}, \gamma_{1 \mathrm{j}}, \gamma_{2 \mathrm{j}}$. 

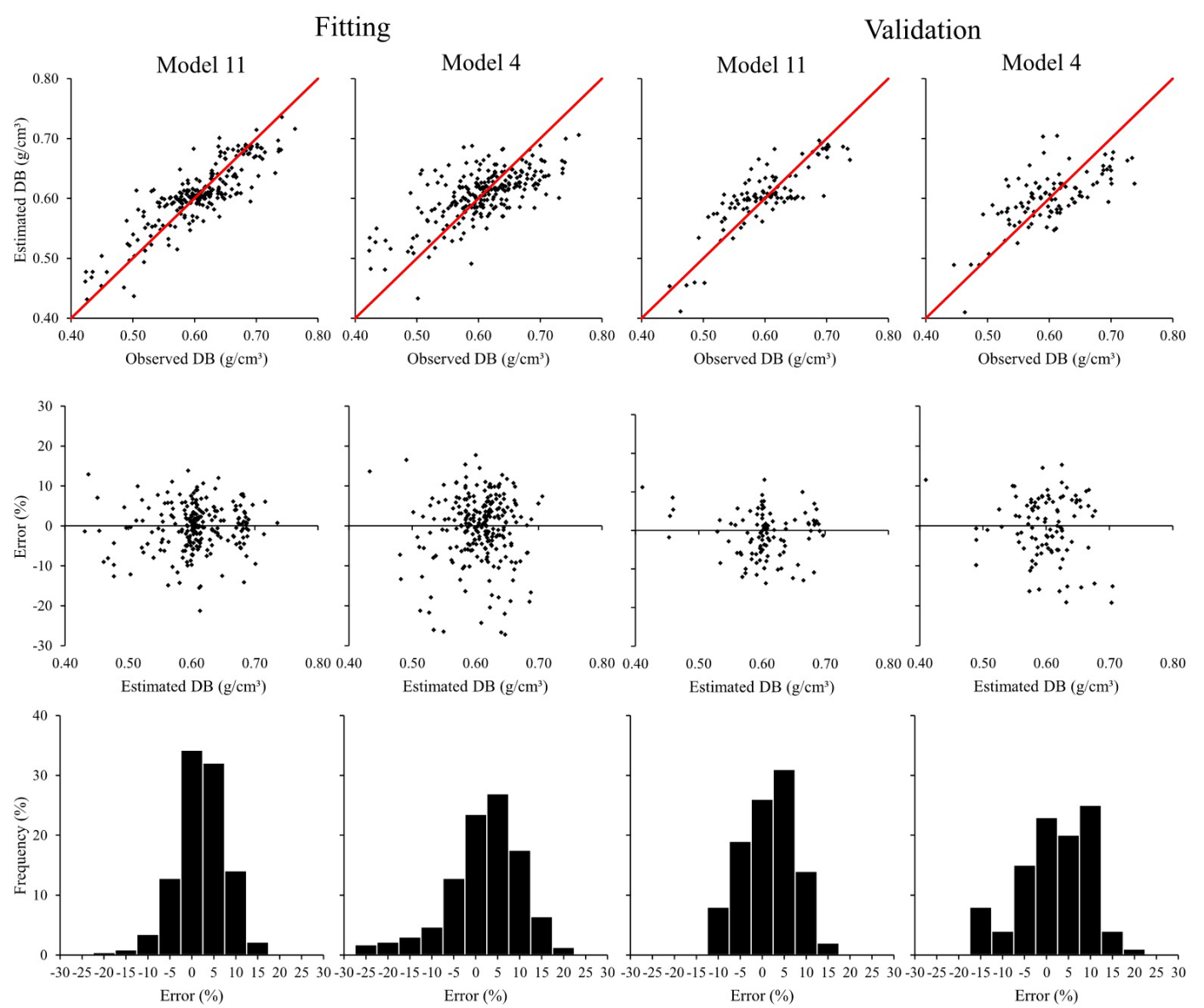

Figure 2. Graphs of observed DB versus estimated DB, residual scatter plot of error percentage as a function of estimated DB, and histogram of the frequency of percentage errors as estimated by Model 11 and Model 4 in the adjustment and validation sets.

The advantage of including the random component in the models was further validated from the residual dispersion graphs shown in Figure 2. Model 11, used to estimate the basic density (DB), presented better residual distribution around the zero error line in comparison to the multiple linear regression model with all fixed effects (Model 4), in both adjustment and validation.

Additionally, the mixed models proposed in the current work presented as a model with the random component of the species, where taking species into account for analysis, implies assigning of lines to each of the considered species, which in turn reduces the error committed by the species. Thus, one can deduce that, in the present investigation, the assignment of lines to each species is the main reason for the reduction of RMSE by $31.21 \%$ in Model 11 as compared to Model 4 .
Since the basic wood density (DB) of native species is frequently used in the estimation of forest biomass and carbon stock, the knowledge about DB aids in the conservation and sustainable exploitation of forests. However, a well-defined behavior is not observed for DB, as it is difficult to estimate due to the variability between the different species. Thus, the use of more accurate statistical techniques, such as mixed models, is a good alternative as it is capable of capturing the relationships of independent variables with pooled data in a better way as compared to traditional regression models.

Further, the DB of wood varies between species (Chave et al., 2006; Maniatis et al., 2011), within the species, and within the tree itself (Wassenberg et al., 2015; Nock et al., 2009; Plourde et al., 2015; Osazuwa Peters et al., 2014; Henry et al., 2010; Deng et al., 2014). These variations are sizeable as well as the changes observed are in line 
with the tree sampling (Pádua et al., 2015). Additionally, studies involving the DB variation of wood of the genus Eucalyptus along with other species (e.g. Cruz et al., 2003) show an increase in the marrow-shell direction and a decrease in the base-top direction.

Thus, wrapping up the observations of the present study, one can state that the PIL, DBH, H, and species can affect the estimation of the basic density of the wood. Moreover, according to Ribeiro \& Zani (1993), the genetic and environmental factors are responsible for variation in the DB of tree wood. Apart from this, the interaction between these two factors also exhibits repercussions on the $\mathrm{DB}$ of wood. This variation of $\mathrm{DB}$ due to the above factors, in turn, can explain the better performance of the models with random effects in comparison to regression models with fixed effects for the estimation of the basic density of Cerrado species.

Conclusively, the method used in the present investigation for estimating the DB of tree wood has great potential. Additionally, carrying out more studies with the combination of other variables in the mixed model, apart from those examined in this study (PIL, DBH, $\mathrm{H}$, and species), can substantially increase the accuracy of the estimates. For example, in the study conducted by Silva et al. (2015), a strong relation (0.94) has been established between the basic wood density of the branches with that of the trunk density of 34 species in the Cerradão de Palmas. Further, harvesting of the trees is not essential for determining the $\mathrm{DB}$ of the branches, as the variable (twig density) could be an alternative to obtain more reliable estimates of the DB of wood. Alternatively, the modeling of variance heterogeneity and autocorrelation can also improve the accuracy of the estimate (Gouveia et al., 2015, Calegario et al., 2005).

\section{CONCLUSION}

In conclusion, the mixed linear models as a superior paradigm exhibited an evident gain in the accuracy of estimation of the basic density (DB) of Cerrado species in comparison to the linear regression model, which takes into account only fixed effects.

\section{ACKNOWLEDGEMENTS}

The authors express their gratitude towards the Foundation for the Support of Research and Innovation of Espírito Santo (FAPES) and the Coordination for the Improvement of Higher Education Personnel (CAPES) for awarding the grants required for the present study, and the National Council for Scientific and Technological Development (CNPq) for the research funding.

\section{SUBMISSION STATUS}

Received: 22 oct., 2018

Accepted: 4 dec., 2018

\section{CORRESPONDENCE TO}

\section{Jeferson Pereira Martins Silva}

Departamento de Ciências Florestais e da Madeira, Universidade Federal do Espírito Santo

- UFES, Av. Governador Carlos Lindemberg,

Centro, CEP 29550-000, Jerônimo Monteiro, ES, Brasil

e-mail: jefersonsb09@hotmail.com

\section{REFERENCES}

American Society for Testing and Materials - ASTM. ASTM D-1037: standard methods of evaluating properties of wood-base fiber and particles materials. Philladelphia: ASTM; 2002.

Angiosperm Phylogeny Group - APG III. An update of the Angiosperm Phylogeny Group classification for the orders and families of flowering plants: APG III. Botanical Journal of the Linnean Society 2009; 161(2): 105-121. http:// dx.doi.org/10.1111/j.1095-8339.2009.00996.x.

Baccini A, Goetz S, Walker WS, Laporte NT, Sun M, Sulla-Menashe D et al. Estimated carbon dioxide emissions from tropical deforestation improved by carbon-density maps. Nature Climate Change 2012; 2(3): 182-185. http:// dx.doi.org/10.1038/nclimate1354.

Bohora SB, Cao QV. Prediction of tree diameter growth using quantile regression and mixed-effects models. Forest Ecology and Management 2014; 319: 62-66. http://dx.doi. org/10.1016/j.foreco.2014.02.006.

Bueno-López SW, Bevilacqua E. Nonlinear mixed model approaches to estimating merchantable bole volume for Pinus occidentalis. iForest-Biogeosciences and Forestry 2012; 5(1): 247-254. http://dx.doi.org/10.3832/ifor0630-005.

Calegario N, Daniels RF, Souza AL, Maestri R. Estimativa do crescimento de povoamentos de Eucalyptus baseada em modelos lineares em multiníveis de efeito misto. Revista Árvore 2005; 29(2): 251-264. http://dx.doi.org/10.1590/ S0100-67622005000200008. 
Cao QV, Wang J. Calibrating fixed-and mixed-effects taper d.,ions. Forest Ecology and Management 2011; 262(4): 671-673. http://dx.doi.org/10.1016/j.foreco.2011.04.039.

Chave J, Andalo C, Brown S, Cairns MA, Chambers JQ, Eamus D et al. Tree allometry and improved estimation of carbon stocks and balance in tropical forests. Oecologia 2005; 145(1): 87-99. http://dx.doi.org/10.1007/s00442005-0100-x. PMid:15971085.

Chave J, Muller-Landau HC, Baker TR, Easdale TA, Steege H, Webb CO. Regional and phylogenetic variation of wood density across 2456 Neotropical tree species. Ecological Applications 2006; 16(6): 2356-2367. http:// dx.doi.org/10.1890/1051-0761(2006)016[2356:RAPVO W]2.0.CO;2. PMid:17205910.

Chave J, Réjou-Méchain M, Búrquez A, Chidumayo E, Colgan MS, Delitti WB et al. Improved allometric models to estimate the aboveground biomass of tropical trees. Global Change Biology 2014; 20(10): 3177-3190. http:// dx.doi.org/10.1111/gcb.12629. PMid:24817483.

Couto AM, Trugilho PF, Neves TA, Protásio TP, Sá VA. Modeling of basic density of wood from Eucalyptus grandis and Eucalyptus urophylla using nondestructive methods. Cerne 2013; 19(1): 27-34. http://dx.doi.org/10.1590/ S0104-77602013000100004.

Cruz CR, Lima JT, Muniz GIB. Variação dentro das árvores e entre clones das propriedades físicas e mecânicas da madeira de híbridos de Eucalyptus. Scientia Forestalis 2003; 64(34): 33-47.

Deng XW, Zhang LY, Lei PF, Xiang WH, Yan WD. Variations of wood basic density with tree age and social classes in the axial direction within Pinus massoniana stems in Southern China. Annals of Forest Science 2014; 71(4): 505. http://dx.doi.org/10.1007/s13595-013-0356-y.

Djomo NA, Picard N, Fayolle A, Henry M, Ngomanda A, Ploton P et al. Tree allometry for estimation of carbon stocks in African tropical forests. Forestry 2016; 89(4): 446-455. http://dx.doi.org/10.1093/forestry/cpw025.

Fausto MA, Carneiro M, Antunes CMF, Pinto JA, Colosimo EA. O modelo de regressão linear misto para dados longitudinais: uma aplicação na análise de dados antropométricos desbalanceados. Cadernos de Saúde Pública 2008; 24(3): 513-524. http://dx.doi.org/10.1590/ S0102-311X2008000300005. PMid:18327439.

Foelkel CEB, Brasil MAM, Barrichelo LEG. Métodos para determinação da densidade básica de cavacos para coníferas e folhosas. IPEF 1971; 2(3): 65-74.

Githiomi JK, Kariuki JG. Wood basic density of Eucalyptus grandis from plantations in central rift valley, Kenya: variation with age, height level and between sapwood and heartwood. Journal of Tropical Forest Science 2010; 22(3): 281-286.

Gómez-García E, Fonseca TF, Crecente Campo F, Almeida LR, Diéguez-Aranda U, Huang S et al. Height-diameter models for maritime pine in Portugal: a comparison of basic, generalized and mixed-effects models. iForestBiogeosciences and Forestry 2016; 9(1): 72-78. http:// dx.doi.org/10.3832/ifor1520-008.

Gouveia JF, Silva JAA, Ferreira RLC, Gadelha FHL, Lima LM Fo. Modelos volumétricos mistos em clones de Eucalyptus no Polo Gesseiro do Araripe, Pernambuco. Floresta 2015; 45(3): 587-598. http://dx.doi.org/10.5380/ rf.v45i3.36844.

Groom JD, Hann DW, Temesgen H. Evaluation of mixedeffects models for predicting Douglas-fir mortality. Forest Ecology and Management 2012; 276: 139-145. http:// dx.doi.org/10.1016/j.foreco.2012.03.029.

Guangyi M, Yujun S, Hao X, De-Miguel S. A mixed-effects model with different strategies for modeling volume in cunninghamia lanceolata plantations. PLoS One 2015; 10(10): e0140095. http://dx.doi.org/10.1371/journal. pone.0140095. PMid:26445505.

Henry M, Besnard A, Asante WA, Eshun J, Adu-Bredu $\mathrm{S}$, Valentini R et al. Wood density, phytomass variations within and among trees, and allometric equations in a tropical rainforest of Africa. Forest Ecology and Management 2010; 260(8): 1375-1388. http://dx.doi.org/10.1016/j. foreco.2010.07.040.

Instituto Nacional de Meteorologia - INMET. Banco de dados meteorológicos para ensino e pesquisa [online]. Brasília: INMET; 2013 [cited 2013 Aug. 21]. Available from: http://www.inmet.gov.br/portal/

Jati SR, Fearnside PM, Barbosa RI. Densidade da madeira de árvores em savanas do norte da Amazônia brasileira. Acta Amazonica 2014; 44(1): 79-86. http://dx.doi.org/10.1590/ S0044-59672014000100008.

Kimberley MO, Cown DJ, McKinley RB, Moore JR, Dowling LJ. Modelling variation in wood density within and among trees in stands of New Zealand-grown radiata pine. New Zealand Journal of Forestry Science 2015; 45(1): 22. http://dx.doi.org/10.1186/s40490-015-0053-8.

Köppen W, Geiger R. Klimate der erde. Gotha: Verlag Justus Perthes; 1928. Wall-map $150 \mathrm{~cm} \times 200 \mathrm{~cm}$.

Latorraca JVF, Albuquerque CEC. Efeito do rápido crescimento sobre as propriedades da madeira. Floresta e Ambiente 2000; 7(1): 279-291.

Leite HG, Binoti DHB, Oliveira N, Lopes PF, de Castro RR, Paulino EJ et al. Artificial neural networks for basic wood density estimation. Scientia Forestalis 2016; 44(109): 149-154.

Maniatis D, Saint André L, Temmerman M, Malhi Y, Beeckman $H$. The potential of using xylarium wood samples for wood density calculations: a comparison of approaches for volume measurement. iForest-Biogeosciences and Forestry. 2011; 4(4): 150-159. http://dx.doi.org/10.3832/ ifor0575-004. 
Mendonça AR, Carvalho SPC, Calegario N. Modelos hipsométricos generalizados mistos na predição da altura de Eucalyptus sp. Cerne 2015; 21(1): 107-115. http://dx.doi. org/10.1590/01047760201521011191.

Meneses VA, Trugilho PF, Calegario N, Leite HG. Efeito da idade e do sítio na densidade básica e produção de massa seca de madeira em um clone do Eucalyptus urophylla. Scientia Forestalis 2015; 43(105): 101-116.

Meng Q, Cieszewski CJ, Madden M, Borders B. A linear mixed-effects model of biomass and volume of trees using Landsat ETM+ images. Forest Ecology and Management 2007; 244(1-3): 93-101. http://dx.doi.org/10.1016/j. foreco.2007.03.056.

Nock CA, Geihofer D, Grabner M, Baker PJ, Bunyavejchewin S, Hietz P. Wood density and its radial variation in six canopy tree species differing in shade-tolerance in western Thailand. Annali di Botanica 2009; 104(2): 297-306. http:// dx.doi.org/10.1093/aob/mcp118. PMid:19454592.

Oliveira GMV, Mello JM, Trugilho PF, Scolforo JRS, Altoé TF, Silva AJ No et al. Efeito do ambiente sobre a densidade da madeira em diferentes fitosionomias do Estado de Minas Gerais. Cerne 2012; 18(2): 345-352. http://dx.doi. org/10.1590/S0104-77602012000200020.

Osazuwa-Peters OL, Wright SJ, Zanne AE. Radial variation in wood specific gravity of tropical tree species differing in growth-mortality strategies. American Journal of Botany 2014; 101(5): 803-811. http://dx.doi.org/10.3732/ ajb.1400040. PMid:24793318.

Özçelik R, Cao QV, Trincado G, Göçer N. Predicting tree height from tree diameter and dominant height using mixed-effects and quantile regression models for two species in Turkey. Forest Ecology and Management 2018; 419-420: 240-248. http://dx.doi.org/10.1016/j. foreco.2018.03.051.

Pádua FA, Trugilho PF, Thiersch CR, Vire MM, Silva JMS. Tamanho amostral para a estimativa da densidade básica em um clone híbrido de Eucalyptus sp. Revista do Instituto Florestal 2015; 27(1): 41-47. http://dx.doi. org/10.4322/rif.2015.004

Plourde BT, Boukili VK, Chazdon RL. Radial changes in wood specific gravity of tropical trees: inter- and intraspecific variation during secondary succession. Functional Ecology 2015; 29(1): 111-120. http://dx.doi. org/10.1111/1365-2435.12305.

R Development Core Team. R: a language and environment for statistical computing [online]. Vienna: R Foundation for Statistical Computing; 2018 [cited 2018 July 4]. Available from: http://www.R-project.org/
Ribeiro FA, Zani J Fo. Variação da densidade básica da madeira em espécies/procedências de Eucalyptus spp. IPEF 1993; 1(46): 76-85.

Rodriguez HG, Maiti R, Kumari A, Sarkar NC. Variability in wood density and wood fibre characterization of woody species and their possible utility in northeastern Mexico. American Journal of Plant Sciences 2016; 7(07): 1139-1150. http://dx.doi.org/10.4236/ajps.2016.77109.

Ruslandi, Cropper WP Jr, Putz FE. Tree diameter increments following silvicultural treatments in a dipterocarp forest in Kalimantan, Indonesia: a mixed-effects modelling approach. Forest Ecology and Management 2017; 396: 195-206. http://dx.doi.org/10.1016/j.foreco.2017.04.025.

Saatchi SS, Harris NL, Brown S, Lefsky M, Mitchard ET, Salas W et al. Benchmark map of forest carbon stocks in tropical regions across three continents. Proceedings of the National Academy of Sciences of the United States of America 2011; 108(24): 98999904. http://dx.doi.org/10.1073/pnas.1019576108. PMid:21628575.

Sette CR Jr, Oliveira IR, Tomazello M Fo, Yamaji FM, Laclau JP. Efeito da idade e posição de amostragem na densidade e características anatômicas da madeira de Eucalyptus grandis. Revista Árvore 2012; 36(6): 1183-1190. http://dx.doi.org/10.1590/S0100-67622012000600019.

Silva CJ, Vale AT, Miguel EP. Densidade básica da madeira de espécies arbóreas de Cerradão no estado de Tocantins. Pesquisa Florestal Brasileira 2015; 35(82): 63-75. http:// dx.doi.org/10.4336/2015.pfb.35.82.822.

Vale AT, Dias ÍS, Santana MAE. Relações entre propriedades químicas, físicas e energéticas da madeira de cinco espécies de Cerrado. Ciência Florestal 2010; 20(1): 137-145. http:// dx.doi.org/10.5902/198050981767.

Wassenberg M, Chiu H-S, Guo W, Spiecker H. Analysis of wood density profiles of tree stems: incorporating vertical variations to optimize wood sampling strategies for density and biomass estimations. Trees 2015; 29(2): 551-561. http://dx.doi.org/10.1007/s00468-014-1134-7.

Xu H, Sun Y, Wang X, Fu Y, Dong Y, Li Y. Nonlinear mixed-effects (NLME) diameter growth models for individual China-fir (Cunninghamia lanceolata) trees in southeast China. PLoS One 2014; 9(8): e104012. http://dx.doi.org/10.1371/journal.pone.0104012. PMid:25084538.

Zhang XQ, Lei YC, Liu XZ. Modeling stand mortality using Poisson mixture models with mixed-effects. ForestBiogeosciences and Forestry 2015; 8(3): 333-338. http:// dx.doi.org/10.3832/ifor1022-008. 